\title{
Interrogating Naturalness of National Identity
}

\author{
Manoj Kumar Mishra ${ }^{1}$
}

Received: 6 March 2020 / Accepted: 27 May 2020 / Published online: 4 June 2020

(c) Fudan University 2020

\begin{abstract}
Nation-state has been considered both an intellectual brainchild and a practical offshoot of the European Enlightenment. The liberal philosophy as an intellectual representative of the Enlightenment tradition and the modernists who emphasize modernization as the practical derivative of it not only deliberated on the simultaneousness and coexistence of the two happenings - the rise of national consciousness on the one hand and appreciation for modern values such as equality, liberty and justice on the other, many theorists argued that these modern values could be realized within a nation-state model (a modern institution). Hence, they contributed to naturalization and de-politicization of the nation-state model. Naturalization/secularization of the nation-state idea without deliberating on the possibilities of politicization and construction of national identities legitimize exclusion of people from national space, drives toward homogenization and nation-building process producing refugees and stateless people. Further, nation-states do not feel the urgency in meeting the normative demands of the international order that strive to defend human rights and address the problem of statelessness. In this context, the article seeks to interrogate the naturalness of national identity of individuals by examining the factors that tend to secularize and naturalize it and by unraveling the real socioeconomic forces that engender and shape national identity and help it look the way it does.
\end{abstract}

Keywords Nation-state $\cdot$ Enlightenment $\cdot$ Modernity $\cdot$ Tradition $\cdot$ Identity politics

\section{Introduction}

Australian philosopher Peter Singer in his essay "Famine, Affluence, and Morality," published in the early 1970s, argued that people could sacrifice morally less significant goods to uphold and contribute to higher moral principles. For instance, contributing some assistance toward saving the lives of starving strangers is morally

Manoj Kumar Mishra

manojhyderabad@gmail.com

1 Department of Political Science, Swami Vivekananda Memorial College (SVM Autonomous College), Jagatsinghpur, Odisha, India 
superior to spending more on additional clothes, fancy dinners and tickets for concerts (Singer 1972). However, the philosopher must have been cautious while prescribing to uphold the principles of higher morality. Nation-states could prioritize irrational expenditure on fellow citizens over meeting morally superior needs of strangers.

\section{Central Argument}

The central argument of the article is while nation-state nowhere took a course of natural evolution not even in Europe where it first emerged; nation-state and national identity have been accepted as secular concepts and foundational elements in conducting domestic as well as global governance. Rise of democratic institutions and forces of modernization strengthened the belief that a clear division has been brought between the era of modernity and that of tradition and nation-states have been built on the ideas of citizens' shared commitment to render service and sacrifice. In a similar vein, many academics in their attempts to secularize the concept of nation-state suggested citizens to imbibe the values of civic nationalism and jettison the role of myths, memories and symbols associated with cultural nationalism. In reality, however, ways to demarcate a clear line between civic and cultural nationalism lack theoretical sophistications as well as practical demonstrations.

The article, citing the examples of nation-building exercises in Europe and nonEuropean societies, strives to point out that there has been coexistence of modernity with tradition as well as civic with cultural nationalism. However, citizens by denying this reality have become a part of politicization of identities and strengthened the role of elites in constructing identities as well as enhancing and preserving their predominance. Identity politics obstructs and obfuscates rational debates on and explanations for the causes of economic inequalities and problems related to migration. Demands for equal rights in identity terms make them look like claims for something special. It is only the recognition that the other person is a human being above all other identities that will help us understand the predicaments of the other.

Yoshihiro Francis Fukuyama-an American political scientist, political economist, and author (known for his book The End of History)_observes: "Nationalists tell the disaffected that they have always been core members of a great nation and that foreigners, immigrants and elites have been conspiring to hold them down" (Fukuyama 2018). They say, "Your country is no longer your own and you are not respected in your own land" (Ibid). Leaders with a cosmopolitan outlook, rather than building solidarity around large collectivities, begin to focus on ever-smaller groups that have found themselves marginalized in specific and unique ways.

Fukuyama suggests strengthening of the American national identity by a universal requirement for national service, underlining the idea that US citizenship demands commitment and sacrifice. He argues that a citizen could perform such service either by enlisting in the military or by working in a civilian role, including teaching in schools or working on publicly funded projects. However, Fukuyama's suggestion of imbibing the values of civic nationalism could not be immune to the wave of cultural nationalism. His suggestions fall flat if one considers the 
rise of nationalist tendencies and far-right parties in the USA and across Europe, respectively.

\section{Significance of the Study}

There has been a growing tide of nationalist sentiments across the globe. While this phenomenon has witnessed electoral successes and swelling of power for some, it has generated feelings of exclusion, marginalization and alienation for many. More tellingly, securitization of religious and ethnic identities by political leaders implying that their communities are under existential threat from certain identity groups is perceptible in many parts of the globe.

Significant electoral gains made by various nationalist and far-right parties across Europe and electoral success as well as rising support for US President Donald Trump's "America first" policies were the results of reactions against crises stemming from uncontrolled migration and financial processes associated with globalization, which brought with it a perceived sense of a dilution of national identity.

Even though Marine Le Pen lost the French presidential election to Emmanuel Macron in May 2017, her efforts at making the far-right National Front more acceptable as an alternative could not be ignored. Le Pen is known for her opposition to the European Union and the euro and for placing the blame on Brussels for mass immigration. Similarly, Hungarian Prime Minister Viktor Orban has not only been a staunch advocate of "defending" Hungary and Europe against Muslim immigrants but raised a specter of "a Europe with a mixed population and no sense of identity" (Aljazeera 2019).

In Germany as well as Austria, the migrant crisis has been the key campaign item determining the electoral success of political leaders. The tough immigration rules in Denmark underline the popularity of the right-wing Danish People's Party. Within the EU, employment concerns and migration overflows have been the key elements in engendering support for Brexit.

It is apparent that a steady rise of cultural nationalism has been witnessed in various parts of the globe as states increasingly resort to religious and cultural precepts to defend themselves from perceived external threats. In the Middle East, while Arab regimes remained concerned with their survival after uprisings on the one hand, regional powers were witnessed accentuating sectarian differences in their quest for regional hegemony on the other. In South Asia, while the dominant ethnic groups remain engaged in a process of reviving, constructing and adapting their identities and political strategies to the evolving context of modernity, the groups, in a way to assert their primacy, selectively emphasize specific periods of history favorable to them on the other. The dominant ethnic groups in these states chose and focused on the historical phase when the religious collectivities constituted their dominant population notwithstanding their history of a common civilization.

For instance, while the states such as India and Nepal hark back to the settlement of the Aryans (Hindus) in the subcontinent, which occurred around 5000 years ago, as the nodal point of history, Sri Lanka, Burma and Bhutan trace their roots back to the mainstream acceptance of Buddhism. The rediscovery of an 
appropriate past when the dominant ethnic group constituted the national mainstream has been crucial to the sustenance of the group's predominance.

The dominant ethnic group in India (Hindus) is a minority ethnic community in Pakistan, and the dominant ethnic group in Pakistan (Sunni Muslims) is an ethnic minority group in India. Both have been accused of threatening their respective minorities, reflecting their historically adversarial relationship.

The dominant ethnic group in Pakistan has not only been allegedly involved in persecuting minority ethnic groups but undertook sustained efforts at assimilating minority groups. The introduction of a subsidy program by Yogi Adityanath, the chief minister of Uttar Pradesh, India, for the Hindu pilgrimage to Kailash Mansarovar in 2017; the BJP's alleged systematic exclusion of Muslim candidates from contesting elections (the party fielded only seven Muslims out of 482 candidates in the 2014 general elections, reducing the Muslim representation in Parliament to 4\% and did not field any Muslim candidates in the 2017 Uttar Pradesh Assembly elections); the party's refusal to condemn the growing problem of cow vigilantism in unambiguous terms; and some leaders' indulgence in Ram Mandir (temple) rhetoric have been viewed as systematic attempts at appeasing as well as promoting the sway of the dominant ethnic group to the exclusion of the minority ethnic community. The government led by Prime Minister Narendra Modi has been accused of forming a 14-member committee of scholars to rewrite history suitable to the dominant ethnic group - the Hindus-after coming to power.

Elites/dominant ethnic groups within various states have become the primary interpreters of the processes of modernization as well as globalization and these processes are perceived by the masses more by the way these are projected than by their unifying potential. Even while globalization is an irreversible process and states' dependence on imports and exports of goods and technology cannot be put to a halt, the global spread of the pandemic covid-19 among others illustrates the flipside of the unfolding dynamics of globalization. The epidemic could cast long-term impacts on the perspectives that guide states' interactions with other states even, while it is true that developing and underdeveloped states would need financial and technological support of other bigger powers to handle crises resulting from the epidemic. The states are likely to be more vigilant on the issues pertaining to the issues of migration, culture and food habits. The elites of the developing and underdeveloped parts of the world are better placed to define the contours of national ethos that would defend their countries from the bitter consequences of globalization. Desperate and less educated masses within developing countries appear to be more prone to the nationalist designs of elites compared to citizens of developed and powerful countries.

The subject under study assumes significance considering the fact that when nationalist sentiments are thriving in many parts of the globe, it is pertinent to understand how an individual becomes a part of a national identity, why the nationalist sentiments appear natural to him/her and what the primary agents of constructing such feelings are. Attempts at understanding these concerns would help the individual generate nuanced perceptions about others within the state. 


\section{Nation-State: A Modern Concept}

The Peace of Westphalia of 1648 ended 30 years of war in Europe and introduced the idea of the modern state defined by the principle of ruler's sovereign control over a specified territory without outside interference. Liberal thinkers and leaders then, inspired by the Enlightenment idea of human freedom, tended to democratize the Westphalian states and international order. US president Woodrow Wilson, taking a cue from liberal tradition, first hailed national self-determination as the organizing principle of the 1919 territorial settlement that then defined the international normative order. In between the Peace of Westphalia and the World War I peace settlement of 1919, popular revolutions in such countries as the USA and France strengthened the idea of the nation-state. The isolationist and arbitrary Westphalian state system characterized by the twin principles of absolute sovereignty and non-interference in domestic affairs has been replaced by an active and democratic liberal international order with the ascendance of norms of democracy and human rights. One of the central ideas of the European Renaissance and the Enlightenment era that followed was to place human reason above supernatural beliefs. The Enlightenment faith in rationality and in evidence that had been gathered from painstaking investigations based on the scientific methods was the harbinger of political notions such as equality, liberty and justice. While the Enlightenment brought ideas about universal moral and political values which transcended borders, ideas of citizenship were also being promoted and were adopted by modern states to protect the interests of individuals living in certain geographic areas. Eventually, ideas about linkages between people who shared common languages and cultures were used to provide the intellectual underpinnings for the birth of the modern nation-state.

Liberal philosophy as an intellectual offshoot of the Enlightenment tradition naturalized and depoliticized the nation-state model and considered it instrumental in protecting modern values such as equality, liberty and justice. The normative international order has been largely shaped by liberal philosophy which justifies "a pluralism of sovereign states allowing for peaceful competition and mutual learning between different constitutional traditions, political cultures, and path of development" (Baubock 2007). It is further based on the notion that "individual liberty can only be defended through facilitating emigration and change of citizenship and preventing the accumulation of uncontrollable political power in global political institutions" (Ibid). The liberal tradition defends a shared identity among people (nation-state) as a prerequisite for securing political obligations, social solidarity and mutual respect for fellow citizens as well as for resisting arbitrary abuses of power.

Contemporary liberal theories defend a thin version of nationalism on the ground that democracy, redistributive justice and welfare of people depend on a conception of national identity based on shared moral beliefs and commitments and that these ideals cannot be achieved at the global level. Liberal theorists argue that a shared identity is prerequisite for ensuring social solidarity that motivates citizens to make the sacrifices necessary not only for political participation 
but also for social redistribution. The sense of obligation that underwrites redistributive taxation derives from a strong sense of attachment to and identification with one's fellow citizens and political community. The contemporary liberal nationalists such as David Miller and Yael Tamir, being aware of the multicultural component of societies, emphasized the importance of a shared national identity to individuals' sense of belonging to a political community over which they could exercise democratic agency. The constitutional patriots, among whom Jurgen Habermas is the most prominent figure and articulated the idea of 'Public Sphere', acknowledged the historical importance of national identity as a source of solidarity among citizens, but hoped that national loyalties could be transferred from cultural nations to specific societies' constitutional traditions (Habermas 1991). He maintains that "citizens can sustain the institutions of freedom only by developing a certain measure of loyalty to their own state" although he acknowledges that this loyalty cannot be legally enforced (Habermas 1992). The scholar, however, did not specify the ways by which loyalty to the constitutional traditions could be insulated from cultural markers, myths and symbols. In a similar vein, the political liberals such as John Rawls and Stephen Macedo although chose to understate the cultural dimension of identity and avoided the language of shared cultural identity, emphasizing instead on the centrality of shared moral beliefs and commitments to the core liberal principles such as equality, basic rights and toleration, they still prescribed a version of shared identity because shared moral commitments could be invoked and enforced through the use of common symbols, language and other cultural markers by the people. The writers understand shared identity as an important, perhaps indispensable, source of the sense of social solidarity that motivates citizens to make the sacrifices necessary not only for political participation, but also for social redistribution (Macedo 2000).

However, the scholars not only fall short of suggesting how the concept of shared identity has to be realized on the ground, their liberal tenets revolve around citizens' freedoms and the universal notions of human rights without reconciling them. This opens up avenues for de-politicization and naturalization national identity and the possibilities of ethnic, religious, linguistic and other cultural aspects of identity (which were supposed to be relegated to the background with the advent of modernity) being invoked for ensuring human freedom increase. There is every possibility that the prescription for a thin version of shared identity would take a thicker form on the ground. Modern scientific theories often fail to recognize that tradition and modernity complement each other in ensuring human freedom and happiness. Religions not only have other-worldly applications; they effectively link this world with the other. The principles of tolerance, egalitarianism, compassion and equality have to be observed in this mundane world for human freedom and happiness. Scientific and rational elements within religions may suggest changes in the way modernity is defined. For example, the Bhutanese state inspired by the Buddhist religion, incorporated the idea of gross national happiness rather than gross domestic product primarily as an indication that a growth in the material accumulation does not guarantee happiness rather the way it is used is more important. Therefore, traditional resources could be resorted to in the modern era in order to shape national identity in a desired way. 
Some liberal scholars clearly defend a liberal version of cultural nationalism. For example, Will Kymlicka and Gans argued that the role of government should be viewed as a means for the preservation of national cultures, which in turn, would provide a necessary background for individual autonomy (Kymlicka 2002). Miller argues that different communities "must abandon values...that are in stark conflict with those of the community as a whole" (Miller 1995).

In practice, however, instead of promoting preservation policies for all cultures, the nationalist elites make concerted efforts to homogenize their languages and culture in a bid to transform the traditional ways of life and strengthen their claims that these originally diverse cultural practices constituted a shared identity.

It is germane to note that at no time in the evolution of any cultural group was there anything like unanimous agreement on defining what it means to be a member of a particular cultural group. Further, any definition that acquires a high degree of consensus within a community at a particular point in its history is subject to redefinition as a consequence of either internal conflicts of interest or ideology within the group or as a consequence of external changes that affect segments of the group differentially.

In this context, Paul Brass acknowledged that the pre-existing cultures or religious practices were not infinitely malleable but emphasized how the role of the elites of the ethnic groups was instrumental in defining, sustaining and providing strength to a particular version of culture. He argued: "In the course of the social and political development of the Muslim community in India during the nineteenth and twentieth century, the symbols used to define its boundaries have varied depending upon the elites who have done the defining" (Brass 1974).

\section{Naturalization and De-politicization of National Identity}

World society contains many normative elements which authoritatively define the nation-state as the preferred form of sovereign and responsible actor. The external recognition and construction of sovereign statehood has been a crucial dimension of the western system for centuries, with new claimants especially depending on obtaining formal recognition from dominant powers. With the anti-colonial and self-determination movements of twentieth century, all sorts of collectivities have learned to organize their claims around a nation-state identity. They have not been able to find any alternative to the "state system" pioneered by the West against whom they had waged the struggle for self-determination in the past. These states also function within the larger discourses of liberalism, multiculturalism and welfare state nationalism as developed in the West. The learning of the smaller states appears complete with the availability of a ready-made formula of state-building and nation-building process (Meyer 1997).

Preservation of democratic governance without disturbing territorial and national integrity of existing states has been recognized as a norm at the global level. By stabilizing the existing states and ensuring their smooth transformation into democratic systems, the international norms stabilize and secularize the existing idea of nation. Under chapters 6 and 7 of the UN Charter, when requested, international 
organizations can and do provide technical assistance in facilitating the transition from a military or authoritarian government to an open system. Such assistance is provided not only by the UN itself, but by several regional organizations and by the Commonwealth. Second, where, the transition turns out to be a source of conflict rather than solution as a result of ethnic or communal conflict, the international community may be drawn in militarily to protect the victims. Similarly, the Commonwealth has made efforts to transform itself into an association of democratic states, and persuaded military regimes, such as those in power in Nigeria and Sierra Leone to conduct elections and implement the Harare Declaration. Existing nationstates by subscribing to democratic governance systems derive legitimacy from the external normative order. It does not matter whether the national culture of the states might have subdued several subaltern identities. Democratic structures matter more than substantive democracy.

The flexibility of the nation-state system has enabled the third world states to keep to their culture and particularistic historical identity along with the adoption of the modern rational models and democratic institutions for apparently secular governance of their societies. It recognizes rights of different minority groups within nation-states so that nation-states appear as a secular political concept and does not get embedded in ethnicity or religion. The international organizations by legitimizing the rights of the minorities and vesting the nation-state with the responsibility to make such rights available have enhanced the legitimacy of the nation-state model. Common evolving world-societal models have led states to establish similar rationalized structures such as ministries and other agencies purporting to manage the socioeconomic planning, education, population control, the environmental science policy, and health and gender equality.

\section{Modernization and Globalization Secularize National Identity}

Growing modernization and irreversible tide of globalization have witnessed states highlighting the incessant flow of capital, labor and technology articulated through their respective national identity. They do not intend to question how the existing national identity came into being. At the same time, the leaders and academics buoyed by economic and technological success tend to ignore the concerns and demands of various subaltern identity groups even though these varied aspects are like two sides of the same coin named "Globalization." Apologists of globalization follow the logic of the modernists who emphasize that socioeconomic and political modernization would gradually replace ethnic, religious and other primordial identities in favor of civic national identities. This reasoning of modernists has not proved right. In fact, these changes have not been able to dismantle cultural, ethnic, religious and sub-national identities. By overlooking the inherent inseparability between modernity and tradition, the apologists of modernization and globalization have only naturalized and secularized the concept of nation-state.

Modernity has not replaced tradition as the latter enjoys mass appeal not only because it provides a sense of rootedness amidst economic, political and social changes, it has also scientific and rational elements (the core elements of modernity) 
within it. For instance, the Bhutanese attempt at redefining its development in terms of Gross National Happiness taking inspiration from the traditional religious prescriptions of Buddhism has been justified in its defense against anti-democratic and consumerist tendencies of globalization. Similarly, forces of modernization and globalization have not prevented fringe groups within many other South Asian countries from making attempts at redefining their nations by invoking rational elements contained in their religions, culture and history. Underlining the inseparability of modernity and tradition, Anthony Smith, a British historical sociologist, observes that in the modern era, the past works through myths, symbols and historical memories in the creation of national culture (Smith 2003). Similarly, the role of a golden past, ancient heroes, myths and memories cannot equip a culture with the necessary material and ideas to shape it into a national culture in the modern period when science and reason rule over dogmas and beliefs. Similarly, John Meyer et al. argue: "Religious 'fundamentalists' may reject the extreme naturalism of modernity by making individuals accountable to an unchallengeable god, but they nevertheless exhort their people to embrace cultural elements (modern ideas) such as nationbuilding, mass schooling, rationalized health care and professionalization. They are apt to reformulate their religious doctrine in accordance with typical modern conceptions of rational-moral discipline" (Meyer 1997).

The process of globalization has led to a greater politicization of identities within nation-states even, while the process tends to legitimize the existing national identity. While the more developed countries want free flow of capital, they wish to see more restrictions in the movement of labor. Uncontrolled migration and shrinking employment opportunities led to the rise of nationalist and far-right parties across Europe. On the other hand, free flow of capital, goods and technology has disturbed traditional balance within many countries of the developing world. Elites on the one hand and masses engaged in indigenous small-scale and handicraft industries on the other perceive the processes of modernization and globalization differently. The negative fallouts of the processes like increasing inequalities both in terms of unequal distribution of wealth and knowledge, displacement and migration push individuals further to cling to their identities at various levels, whereas elites keep engaged in constructing a national culture suitable to their interests.

While the forces of modernization and globalization did not intend to dilute individuals' loyalty to their nation-states, it only helped in depoliticizing and naturalizing the existing nation-states. A cursory look at the wave of integration that started in Europe in the 1980s would make it clear that it was primarily a reaction to the increasing pressures of global markets with the purpose of formulating common economic policies. Though European Union (EU) is known for free movement of people, free trade and political participation across the member states, the EU had never intended to bypass the nation-state system and instead offered a vision where nation-states could coexist with other institutions at multiple levels. For instance, while the EU was trying to bring Hungary back into the European club of prosperous democratic states, at the same time, it was attempting to satisfy the Hungarian desire to have closer ties with the Hungarians living in the neighboring states. In the case of Macedonia, European Union played an important role in stabilizing the nation-state by bringing majority and minority communities to negotiating table. 


\section{Weaker Human Rights Versus National Identity}

Weak human rights norms at the international level fail to uphold individual rights and rights of minority groups when a particular version of national identity seeks to exclude and marginalize them. Hence, these norms cannot challenge the claims of nation-states which are projected to be natural and secular. Although human rights have been incorporated into international declarations and conventions turning individuals into subjects of international law like states, individuals and states enjoy unequal status within international law as individuals are considered merely bearers of rights and not authors of law like states. Human rights norms are negotiated and adopted by the governments of sovereign states, and more tellingly, the adjudication of human rights in the UN system does not allow individuals to appeal directly to an international court against their governments. It is noteworthy that groups or associations at intermediate levels between individuals and states have no firm place in international law. Even the cultural minority rights of Article 27 of the International Covenant for Civil and Political Rights (ICCPR) from 1966 are not formulated as group rights, but as rights of individual persons to enjoy "in community with the other members of their group...their own culture, to profess and practice their own religion, or to use their own language" (Saul 2000).

However, by employing the words "in those states in which...minorities exist," Article 27 leaves the option to the states to declare that they have no minorities, thereby excluding its application to persons within their territory or subject to their jurisdiction. Second, the rights provided in Article 27 are conferred on persons belonging to ethnic, religious or linguistic minorities. It is not clear whether citizenship is a precondition for invoking Article 27 and whether indigenous groups are entitled to the rights which the article provides. Third, Article 27 is the only provision in the Covenant which is negatively phrased. Instead of stating that persons belonging to minorities "shall have" the rights specified, it declares that they "shall not be denied" those rights. The exact meaning of this phrase has been the subject of much debate, carried on to this day. Finally, the text also leaves ample room for interpretation regarding the subjects-individuals or groups-to which it applies (Preece 1998).

The right to self-determination has not found a reference in the Universal Declaration of Human Rights. However, two major human rights Covenants, International Covenant on Civil and Political Rights and the International Covenant on Economic, Social and Cultural Rights mention it in their first article. The UN General Assembly's 1960 Declaration on the Granting of Independence to Colonial Countries and Peoples stipulates at paragraph 6 that any attempt at the partial or total disruption of the national unity and the territorial integrity of a country is incompatible with the purposes and principles of the Charter of the United Nations. The 1970 Declaration on Principles of International Law Concerning Friendly Relations and Co-operation Among States in Accordance with the Charter of the United Nations-adopted by the General Assembly goes on to affirm the fundamental limitation to the right to self-determination set out and expressed in the 1960 Declaration. 
Weaker status of human rights compared to nation-states has led the modern state to seize the Universal Language of Enlightenment in its favor. The modern state has become the upholder of people's rights, liberty and equality. However, the possibility of politicization of religious and ethnic identities has not diminished as they can be tied to modern aspirations of human freedom. Elites who have influence over the modern state apparatuses can manipulate these primordial sentiments and make selective use of symbols and ethnic markers to promote their own socioeconomic interests. The emotive and indigenous element of identity propel the elites to use it as the basis of their rise to power, and on the other hand, the influence that elites exercise over decision-making process enables them to distribute welfare goods and influence identity groups in a desired way. As it has been observed, uneven tendencies of globalization can lead to greater politicization of identities thereby making it banal.

\section{Identity: A Domestic Issue}

As almost all the states are multicultural and individuals have multiple identities, it is not surprising that nation-building process tries to promote common norms and values to provide legitimacy to states including the smaller ones. This fact has lessened interference of states in others' nation-building process unless serious strategic considerations are involved in that misadventure.

A state's support for minorities in another state increases demands of its own minorities, which get their support from their ethnic brethren in other states. A state's conspiracy against minorities of another state makes the former bear the wrath of its own minorities. Identity, so far, is considered a domestic affair. Interference in other states on identity issue invites sanctions and international condemnation. For example, Serbia in former Yugoslavia faced international sanctions and embargos when it interfered in Croatia and Bosnia's internal affairs in a bid to unite Serbian minority in those states and establish a safe haven for all Serbians. Furthermore, using ethnicity as a component of a state's foreign policy may have dangerous implications. It may legitimize the action of other states that have ethnic interests in the given state. There have been occasions when a state is forced to interfere in the affairs of another state primarily to assuage rising disaffections emanating from certain provinces of the state given the people of the provinces share the same ethnicity with those of the minorities of another state. But such interference depends on the homogeneity of the people of the state as people of other provinces may oppose such move.

As most of the states are multicultural such policies are less liable to success. Again, such policies of a state may invite international sanctions or use of ethnicity as an instrument of foreign policy by some other states against it. There are, of course, instances of intervention along with the use of military power by the USA in the Gulf, international forces policing the Balkans, going after Serbs in Kosovo and Serbia, and Australia doing its bit for international law and order in East Timor, but these interventions were the outcome of convergence of strategic interests of the major powers. Second, the UN, in most cases, has been used as the necessary 
platform by the major powers to elicit world public opinion in their favor and both NATO and the UN Security Council, most of the permanent members of which are also the members the former played an important role in Yugoslavia (Sperotto 2008). However, such extraordinary circumstances when the strategic interests of the great powers converge have not come in case of many smaller states lacking geostrategic importance. National identity is still considered an internal issue although forging it often sacrifices human rights and minority rights in the process.

The international normative order has been shaped by the values of powerful states which in turn casts its impact on individual states in the long-term. Colonialism was opposed by the third world countries (then colonies) as an oppressive alien western institution. However, the nation-state model, first developed in the west, was accepted and adopted by the third world states subsequently as they began to contribute to enrich the understanding and application of the concept by becoming parts of the democratic structures of the UN and other allied agencies. The idea of popular sovereignty which found an expression in the anti-colonial movements of the third world countries received a formal recognition with the inclusion of these countries as the members of several international bodies like the UN and other allied institutions, and consequently, various rationalized models of development were accepted and adopted by these countries. The role of the international organizations shared the goal of national integration largely shaped by liberal philosophy justifying the requirement of a shared identity for effective governance of a state. For instance, the Organization for African Unity (OAU) is committed to the notion that boundaries established by the colonial rulers be kept intact and the UN Charter stipulates protection of the sovereignty and territorial integrity of its member states.

By spreading nation-building rather than self-determination as public good, the nation-state system stabilizes itself by not allowing umpteen number of ethnic clashes and unending process of nation-state creation. The idea of nation has been grafted onto the Afro-Asian landmass which has been apparently at odds with the evolution of these societies. However, these nations-in-making derive their legitimacy from the international normative order and could claim to be guardians of popular sovereignty. While historically, frontiers (which kept on waxing and waning) with its flexibility and openness determined the territorial sway of kingdoms and tribal system of governance and many ethnic and sociocultural groups continued to define their existence within the loose territorial space, tight yet unresolved borders were forged by the imperial system for the convenience of its administration. For instance, the Indian subcontinent was artificially divided by the British colonial administration to facilitate its rule resulting in either separation or merging of sociocultural groups contradicting the history of their evolution.

In the continents of Asia and Africa, modern state system with fixed territoriality and sovereignty was imposed by the colonial powers which later adapted the western model of nation-state through nation-building exercises even though these states had been created artificially without adequate attention to the lived experiences of sociocultural and ethnic groups and in most cases, borders remained as unresolved political issues. More than physical partition which continue to haunt the third world societies is that in their bid to become nations they engage poets and historians in defining and interpreting histories which project them culturally different from other societies. 
Politicians engage in rhetoric and selectively choose symbols which push the countries to look away from each other further. Intellectual partition is a process which strives to artificially construct nations through selective memory and collective amnesia. Modern scientific theories such as liberalism and multiculturalism even while trace their origin to the European Enlightenment; these have been instrumental in rationalizing, democratizing and modernizing the traditions of the third world countries. Though some of the postulates of these theories have been condemned as purely western, the spirit underlying these theories has been instrumental in reflecting on developing countries' traditions as to how best these countries have been able to protect popular sovereignty, individual rights and group rights. People exposed to media, internet and television take note of how the ideals of Enlightenment are being protected in other countries.

\section{Politicization of Identities}

The difference between the pre-modern and modern state is that the latter derives its legitimacy from people. Nationalism is considered essential to unite people and connect them with the state thereby making the modern state a nation-state. The theoretical traditions inspired by the Enlightenment ideas of human freedom and welfare such as contemporary liberalism, multiculturalism and welfare state nationalism elaborate upon the need of a shared identity, solidarity, recognition, and patriotism for effective governance of people, protection of human freedom and promotion of human welfare. However, many scholars like F. W. Riggs, E. Gellner, S. Huntington, Breuilly and Walker Conner, on the other hand, pointed to the political, economic and social forces responsible for the growth of nationalism in a modern state thus making it a nation-state. They were keen to see how the Enlightenment belief in science and reason gave birth to the practice of viewing them both as a means and as an end relegating the idea of human freedom to a secondary place and leaving its contours being shaped by various socioeconomic, scientific and technical forces.

While a focus on the socioeconomic, scientific and technical forces pointed to the role and interests of the ruling elite in the evolution of modern state and nationalism, the idea of human freedom inspired by the European Enlightenment looks to the interests of the people. Taking stock of the role of the socioeconomic and political interests on the one hand and the idea of equality, liberty, justice and popular aspirations to form self-government on the other, as the background to the birth of modern state, the author discusses the nature and working of the modern state. A closer look at the interactions between the practices and norms would show a convergence of interests privileging the predominant pre-modern forces to reproduce the nationstate in a desired way.

\section{Elites and Nationalism}

In the nineteenth century Europe, it was the bourgeoisie which employed the regulatory capacities of the state apparatus to monitor and oversee the gradual incorporation of select subaltern groups into the political community although the 
universalistic and inclusive discourse of the Enlightenment was used in the process. According to F. W. Riggs, the success of industrial revolution depended on the widespread acceptance of the idea of nation as the basic source of political legitimacy (Riggs 1998). An industrializing state as an organization of mass production and marketing required a popular base. Thus, two processes began as the leaders wanted to create popular bases for themselves and people, for the first time, became able to influence policy making as they became politically important. According to him, industrialization, democracy and national identity are part and parcel of the modern state (Ibid). Gellner associated modernity with the spread of industrialization. According to him, the latter led to an unprecedented and all-pervasive change which disrupted the traditional balance of society, creating new constellations of shared interests. For Gellner, nationalism was the offspring of the marriage between state and culture, and the latter was celebrated on the altar of modernity (Gellner 1983). Therefore, scholars like Pandey and Geschiere argue "Along with, perhaps more than the Enlightenment ideas and notions of the 'rights of man', conquest and capitalism were the harbingers of the new world" (Pandey and Geschiere 2003).

It can be argued that a modern state relies on a single national identity rather than supernatural or hierarchical sources of authority in order to ensure a democratic base for itself for industrial development and achieve other group objectives by acting against external enemy and meeting the welfare needs of the people. However, the origin of nationalism in many places points to the fact that the conditions for its emergence were largely shaped by the elites for their self interests, and hence, they were imperfectly actualized. Providing the socioeconomic thrust to the evolution of nations, some of the Soviet anthropologists have delineated the historical ramifications of various stages in the evolution of ethnic groups to the status of nations or nationalities. However, in terms of their historical placement of the term 'nation' they came closer to the "modernists' to the extent that they posited the evolution of nations along various stages of the evolution and growth of capitalism (Phadnis and Ganguly 2001).

In marked contrast to Europe where socioeconomic factors were instrumental in the formation of national identity overriding many particularistic identity claims and excluding many marginalized identities from the national space, the Chachapoyas movement in Peru, was led by the people themselves against the entrenched aristocracy and was based on local culture, however, subsequently leading to the exclusion of marginalized groups on the basis of socioeconomic interests. Modernity made people the reference point of all the religions and cultural practices and created hope among the masses that the aristocratic rule based on a feudalistic conception of sovereignty would end ushering in modern states in many pockets of the world. Where there was no self-conscious modern bourgeois class committed to the principles of popular sovereignty to seize the control of the state apparatus unlike what happened in Europe, it was the people themselves who challenged feudalism and defined the national culture. It needs to be underlined that national cultures are not always constructed from above resulting in the imposition of a unitary and homogenous national essence on subject populations with their distinct local cultures. Rather, in the making of the national cultures, the periphery may reach toward the centre to embrace the nation as much as the 
centre reaches out to the periphery. David Nugent argues in his article Modernity at the edge of Empire that there was no self-conscious modern bourgeois class in Peru and the state could be conceived as a "pseudo-state" which remained in the hands of shifting groups of regional elites who were strongly wedded to the notions of aristocratic sovereignty (Nugent 1997).

It is interesting to note that in its challenge to the aristocratic order, the movement of the people in Peru openly embraced "things modern" and "things national." In addition to the challenge of getting rid of the exclusionary racial divisions by reconfiguring history and reconceptualizing space, the challenge also included accepting modern notions of discipline, order, hygiene and morality. For this, "personal" characteristics were seen as the antithesis of the violent and abusive behavior of the decadent aristocratic elite. The new cultural identity and alternative moral universe emerged from within the movement of democratization and appeared to the movement participants as their own creation authored by the people themselves and not imposed or arbitrary, and reflected the region's most essential and enduring characteristics (Ibid).

This is not to say, however, that the image of society and personhood contained within the discourse of popular sovereignty corresponded to the actual social conditions. Exclusion was an integral part of the movement. Democratization meant not only the empowerment of the urban, male middle class, but also the systematic exclusion of women and peasants from the more "open" society envisaged within the movement. Even though the transformations in local life brought about by the movement were consistently cast in the universalistic language of the Enlightenment, these changes represented the interests and motivations of particular groups. The instances of exclusion built into the very process of state-building and nationbuilding surfaced in subsequent decades. It can be argued quite contrary to the argument of the primordialists that ethnicity (including distinctions based on religious, cultural and linguistic factors) in a modern state is susceptible to socioeconomic and political variables. Socioeconomic and political factors are not simply external to the dynamics of ethnicity rather they are quite intrinsic and fundamental in determining the shape of identity (Nugent 1996).

Both the European and Peruvian cases substantiate that identity and socioeconomic interests reinforce each other. Three factors-socioeconomic interests, the Enlightenment norms and identity-must be balanced against each other by the powerful groups in order to be instrumental in the formation and domination of the modern state. The modern state becomes an apparatus through which the socioeconomic interests of the elites are sustained and promoted by astute use of identity in the modern language of welfare and justice. Developing and pursuing proper strategies in promoting specific identity groups gives elites the desired benefits in socioeconomic terms. Likewise, the distribution of socioeconomic privileges in a society defines and provides a specific shape to the structure of identity. In this context, it is apt to argue that the primordialists and the perennialists while ascribe importance to the historical role of identity and identity groups, they lose sight of the socioeconomic dimension in the process of the construction of national identity out of disparate primordial identities. The modernists, on the other hand, overemphasize the socioeconomic factors at the cost of the historical role of identities. 
The fact that that needs to be underlined is that both the schools fail to see how identities and socioeconomic interests can be pursued at the behest of one another. The modern nation-state, which regulates the affairs of a society through coercive power and derives its legitimacy from the institutionalization of the Enlightenment norms, becomes a medium for the interplay of identity claims and socioeconomic interests. Therefore, political power becomes indispensable for the realization of the socioeconomic interests of the elites. The elites cannot pursue identity or socioeconomic interests politically unless they tie them to the Enlightenment norms of popular sovereignty, liberty, equality, justice and welfare of masses. The modern state, as the embodiment of the Enlightenment norms, has both the coercive and extractive power. Coercive power is necessary to work for the common objectives by regulating behavior of the masses and extractive power to generate resources to undertake welfare measures. However, there are examples where the three factors, namely socioeconomic interests, the Enlightenment norms and identity claims were not suitably combined leading to the political death of the privileged groups. In Sikkim, presently an Indian province, the ruler Chogyal failed to create a national identity because he was moved by narrow political interests without thinking to balance them with identity claims and the Enlightenment norms or popular aspirations for liberty, equality and justice leading to his political death and subsequent annexation of Sikkim to India. Chogyal was reluctant to become a constitutional head and resisted to transfer the reserved subjects to any elected government. He wanted to remain as the chief executive of Sikkim combining all the powers in him which resulted in popular uprising in 1973 (Das 1983).

The ruler was of Tibetan origin belonging to the Bhutia community. The Bhutia contact with Tibet was limited to aristocracy in Sikkim who intermarried there and conducted business. The majority of the Bhutias had no attachment to Tibet nor had Sikkim's personality evolved to an extent where they had any significant understanding or involvement in the nationalistic sentiments. The nationalistic sentiments were confined to the educated elite who constituted a small minority. Lepchas, the second largest community, had been neglected and suppressed linguistically and culturally ever since the Bhutia invaders came in 1641. The Kazi aristocracy, among the Bhutias, played an economic havoc. They stood by the ruler as long as their socioeconomic interests were promoted by the ruler, once they saw the power shifting from the Chogyal to Delhi; they joined the mainstream being assured of the economic and cultural interests fully protected (Ibid).

The institutionalization of the Enlightenment norms by the modern state, the liberal theoretical tradition's exhortation for loyalty to the political community and moreover, the prospect of use of religious or any ethnic identity for ensuring human freedom provide ample scope to the elites of the dominant ethnicity to manipulate symbols and other ethnic markers to promote their socioeconomic interests. The emotive power behind and indigenousness of identity propels the elites to use identity as the basis of their rise to power, whereas the state's authority to distribute welfare goods and modernize society provides the elites with opportunities to influence identity groups in a particular way. At times, a particular identity is subjected to a particular mode of socioeconomic distribution. This is how socioeconomic and political power and identity are mutually re-enforcing (Mishra 2016). 
Dominant ethnicities are born out of three possibilities in a modern state. First, where there is self-conscious bourgeoisie as the European case suggested, used identity for socioeconomic and political interests and formed dominant ethnicity. Second, where the people led the fight against aristocratic rule inspired by the European Enlightenment norms and became the true interpreters of identity and formed dominant ethnicity as the Chachapoyas case suggested. The second possibility is applicable to many third world colonial states as well. Third, in the absence of selfconscious bourgeoisie and without a colonial history, the rulers used identity to preserve the socioeconomic and political privileges of the pre-modern era by adopting the Enlightenment norms in order to stay in power and help form dominant ethnicity as the case of Bhutan suggested.

\section{Socioeconomic Drivers of Nationalism and Modern State}

It is clear that national culture can come from below by uniting the people on the basis of the Enlightenment ideas like popular sovereignty, equality, liberty and justice. However, even in the cases of upward movement of nationalism as the Chachapoyas case pointed out, the socioeconomic factors influence people's movement by becoming instrumental in associating political power with the better off and excluding the worse off. And once the modern state is established, the very national culture based on the Enlightenment ideas is likely to be reinterpreted to suit the interests of the elites who happen to be the products of modernity and who control the modern tools like press, education and electronic media to a large extent to reach out to the people. While Anthony Smith argues that it is possible to date an embryonic development of modern nations back to ancestral times, Walker Conner retorts by arguing that such a task would be purely speculative and contain sweeping explanations. If nationalism is a mass-not elite-phenomenon, then it can only occur at a quite advanced stage of modernity: That is when the development of modern mass communication makes it possible for an elite group to spread national identification among the larger sections of population (Conner 2004). Modernists also differ in their emphasis while insisting on the modernity-nationalism linkage. For example, Breuilly locates the core of modernity in the modern state, Anderson in the printing press, Conner in the modern communications and Gellner in the industrialization process.

Samuel Huntington seems to have used modernity to mean the dialectical relationships between the modernizing society, which includes developments in printing, mass education, industrialization, etc., and the modern state. According to him, modernization can involve changes not only in the distribution of power within a political system but also in the amount of power within that system. Absolute monarchies and feudal states contain only a small amount power, which grows as modernization proceeds. An increase in the quantity of power in a system must also bring about an increase in the amount of competition for that power. Existing powers and privileges must be protected more energetically in circumstances where new spheres of competition threaten to change the existing distribution of power. As the scope of social mobilization extends deeper into a society as a result of modernizing 
initiatives such as mass education, the problem of integrating primordial social forces into a single national political community becomes more urgent (Huntington 1968).

It is argued that the newly democratizing states as a result of modernity can set in motion a number of forces that ultimately bring about a shift in individuals' primary political identification from membership in an associative civil state to membership in a particular ethnic or religious nation. Dictatorial regimes face no active opposition to their ruling because legitimacy to their rule does not depend on popular consent, and thus, they face little need to compete for the mantle of popular legitimacy by whipping up mass enthusiasms. Unleashing mass nationalism would only hinder their goal of depoliticizing domestic politics and would introduce needless complications into their management of foreign relations. Especially, prone to myth making are the situations of partial monopoly over supply of ideas in the market place of ideas, which often occur during the earliest stage of democratization due to the struggle between the traditional power holders and the new claimants to the leadership position (Snyder and Ballentine 1997). Thus, modernity which brings people and state closer may also create problems for the ruling elites as people secure different channels to oppose governments or force them to distribute resources in a particular way or stake claims to share political power. In the third world, modernity shaped nationalism in two ways. First, in the colonies, social political elites played a major role in fostering nationalism by rallying masses around the Enlightenment norms against the colonial power and became instrumental in the formation of the modern state. Second, in some states, like Bhutan, traditional elites realizing the necessity of finding legitimacy in a secular democratic age shaped by the Enlightenment ideals, sought to incorporate the masses by claiming a role as the permanent guardians of national continuity as the Prussian monarchy and land-owning aristocracy did in the post-1871 Germany.

In present times, highly bureaucratized states with emphasis on modernization and welfare activities invoke national identity to fulfill their aims of not only sustaining the already available power but generating more power. This has, consequently, led to politicization of identity, which may not uphold the interests of different communities as such definitions of national identity are driven more by the necessity to meet political expediency than to meet and promote the interests of the communities. Elites of different communities also create their power bases by defining and redefining the identity of the communities in relation to the state so that they can direct welfare resources and modernization process in a particular way, and moreover, they carry with them the ultimate objective of controlling the state apparatus.

A closer look at the Indian history points to the same fact- "The definition of the Muslim community articulated by the modernizing Muslim elites associated with Sayyid Ahmad Khan and the Aligarh movement was a political one." In contrast to the ulema, who attached most value to the symbols of Muslim identity that not only separated Muslims from non-Muslims but isolated Muslims from contamination by alien religious and legal influences and preserved the influence of the ulema within the Muslim community, the modernist elites were interested in using the community as a base for the exercise of influence in the wider society. The Muslim aristocrats and government servants who founded the various institutions associated with the 
Aligarh movement moved in the same sphere as, and had similar interests to those of their Hindu counter parts" (Brass 1991).

Most of the times, nationalism was successfully forged by the presence or deliberate creation of out-groups by elites. For example, in colonies repeated and institutionalized references to successful struggle for independence from the colonial power were generally considered a highly useful tool for nation-building. In the cases of states which were never colonized like Bhutan, the success of nationalism depended on the success of the political elites in identifying some other outgroup and molding the struggle into a legitimizing history and the foundation of its national identity.

\section{Conclusion}

The concept of nation-state has been naturalized and depoliticized by many factors tracing their origin to the modern era. As a result, a tendency of treating national identity as a byproduct of a natural process has taken attention away from the ways and means it is constructed by elites in a desired way. In this context, exploring the socioeconomic and political background behind the rise of the modern nation-states contributes to the understanding of the political nature of identity. It lays bare the role of elites in sustaining a particular version of national identity in support of their socioeconomic and political interests by the means of controlling the state apparatus. The article finds that identities cannot be engineered according to someone's whims and fancies (as some modernists claim) as they show remarkable persistence in some cases in the face of socioeconomic and political modernization, nor should they be considered entirely hermetically sealed entities that cannot be constructed.

In all the developing countries, the state is seen as the principal instrument of modernization and the process of modernization requires involvement of people and their participation is the key to the success of the developmental activities undertaken by the state. Consequently, though safeguarding people's interests is the natural outcome of modernization, they are cast in the universalistic language of the Enlightenment evoking the principles of equality, liberty and justice by the elites of the modern state. People who are divided along caste, class, gender, ethnic and religious lines, find it inconvenient to challenge the state which is considered as the embodiment of the Enlightenment principles of equality, liberty and justice.

While people's dependence on modernization process and welfare activities has inflated the power bases of elites in the modern state, people have been mobilized along traditional ethnic and religious myths and symbols either against the state for redistribution of welfare goods in a desired way or by the state directing the modernization projects in particular ways. Increased localization and democratization of identity has effectively linked identity with the popular concepts of equality, liberty and justice and provided reasons to act for its preservation and promotion. Democratization of identity has shifted rationalization of it by the Church or king to academics, various political and public bodies and media. The intellectuals forming the world of academia have exerted decisive impact on human reason, while media and political leaders played on human emotions. 


\section{Compliance with Ethical Standards}

Conflict of interest The authors declare that they have no conflict of interest.

\section{References}

Baubock, Rainer. 2007. Political boundaries in a multilevel democracy. In Identities, affiliations, and allegiances, ed. Seyla Benhabib et al., 233. London: Cambridge University Press.

Brass, Paul. 1974. Language, religion and politics in North India. Cambridge: Cambridge University Press.

Brass, Paul. 1991. Ethnicity and nationalism: Theory and comparison, 90-91. New Delhi: Sage.

Conner, Walker. 2004. Resisting primordialism. In Ethnonationalism in contemporary world, ed. Daniele Conversi, 269-290. London: Routledge.

Das, Brajbir Saran. 1983. The Sikkim saga. New Delhi: Vikas Publishing House.

Fukuyama, Francis. 2018. Against identity politics: The new tribalism and the crisis of democracy. Foreign Affairs 97 (5): 90-112.

Gellner, Ernest. 1983. Nations and nationalism. Oxford: Blackwell publishers.

Habermas, Jurgen. 1991. Structural transformation of the public sphere: An inquiry into a category of bourgeoisie society. Cambridge: MIT Press.

Habermas, Jurgen. 1992. Struggles for recognition in the democratic constitutional state. In Multiculturalism: Examining the politics of recognition, ed. A. Gutmann, 135. Princeton: Princeton University Press.

Hungary’s Orban vows defence of 'Christian' Europe, February 11, 2019. Aljazeera News. https://www. aljazeera.com/news/2019/02/hungary-orban-vows-defence-christian-europe-190210195421238 .html. Accessed 10 June 2019.

Huntington, Samuel P. 1968. Political order in changing societies, 145. New Haven: Yale University Press.

Kymlicka, Will. 2002. Contemporary political philosophy: An introduction, 365. New York: Oxford University Press.

Macedo, Stephen. 2000. Diversity and distrust: Civic education in a multicultural democracy, 146. Camridge, MA: Harvard University Press.

Meyer, John W. 1997. World society and the nation-state. American Journal of Sociology 103 (1): 144-181.

Miller, David. 1995. On nationality, 72. Oxford: Clarendon Press.

Mishra, Manoj K. 2016. Ubiquity of identities in the era of globalization. Eurasia Review. https://www. eurasiareview.com/17012016-ubiquity-of-identities-in-the-era-of-globalization-oped/. Accessed 9 May 2018

Nugent, David. 1996. From devil pact to drug deals: Commerce, unnatural accumulation and moral economy in modern Peru. American Ethnologist 23 (2): 382-397.

Nugent, David. 1997. Modernity at the edge of empire: State, individual, and nation in the Northern Peruvian Andes, 1885-1935, 319-320. Stanford: Stanford University Press.

Pandey, Gyanendra, and Peter Geschiere. 2003. The forging of nationhood, 10-26. New Delhi: Manohar Publications.

Phadnis, Urmila, and Rajat Ganguly. 2001. Ethnicity and nation-building in South Asia, 51. New Delhi: Sage.

Preece, Jennifer Jackson. 1998. Ethnic cleansing as an instrument of nation-state creation: Changing state practices and evolving legal norms. Human Rights Quarterly 20: 827.

Riggs, Fred W. 1998. The modernity of ethnic identity and conflict. International Political Science Review 19 (3): 276.

Saul, Ben. 2000. Cultural nationalism, self-determination and human rights in Bhutan. International Journal of Refugee Law 12: 339.

Singer, Peter. 1972. Famine, affluence, and morality. Philosophy \& Public Affairs 1 (3): 229-243.

Smith, Anthony. 2003. Chosen peoples: Sacred sources of national identity. Oxford: Oxford University Press. 
Snyder, Jack, and Karen Ballentine. 1997. Nationalism and the marketplace of ideas. In Nationalism and ethnic conflict, ed. Michael Brown et al., 71. Massachusetts: The MIT Press.

Sperotto, Federico. 2008. The international security presence in Kosovo and the protection of human rights, working paper no. 48. http://www.du.edu/gsis/hrhw/working/2008/48-sperotto-2008.pdf.

Dr. Manoj Kumar Mishra has a Ph.D. in International Relations from the Department of Political Science, University of Hyderabad, India. Currently, he is working as a Lecturer at the Department of Political Science, Swami Vivekananda Memorial College (SVM Autonomous College), Jagatsinghpur, Odisha, India. Previously, he served as the program coordinator at the School of International Studies at Ravenshaw University in Odisha, India, and was also engaged in teaching Theories of International Relations and India's Foreign Policy to M.A. and M.Phil. students. He has many published articles and commentaries in journals and magazines such as the Georgetown Journal of International Affairs (Online Edition), Afro Eurasian Studies, World Affairs, South Asia Journal, Journal of Peace Studies, Asia Times, Foreign Policy Research Journal, The Indian Journal of Political Science and Eurasia Review and International Policy Digest. 